DOI: $10.2478 /$ lpts-2014-0026

\title{
OPTICAL MICROSTRUCTURES FABRICATED WITH DIRECT LASER WRITING TECHNIQUE
}

\author{
M. Kowalczyk, M. Nawrot, and L. Zinkiewicz \\ Photonic Nanostructure Facility, Institute of Experimental Physics, \\ Faculty of Physics, University of Warsaw, \\ 69 Hoza Str., 00-681, Warsaw, POLAND \\ e-mail: michal.nawrot@fuw.edu.pl
}

\begin{abstract}
Three-dimensional photolitography, also known as Direct Laser Writing (DLW), is a powerful technique for fabrication of photonic microstructures. In this paper we present the basics of the relevant technology and discuss some features of the fabrication process. We also describe the experimental setup designed for making colour filters based on diffraction gratings, fibretip-integrated lens and anti-reflective coating designed for telecom wavelength $(1550 \mathrm{~nm})$. The results obtained demonstrate the DLW technique to be a promising fast prototyping fabrication method that may allow manipulating the properties of optical materials.
\end{abstract}

Keywords: Direct Laser Writing, 3D photolithography, photonic structures, AR coating, colour filters.

\section{INTRODUCTION}

In 1987, Eli Yablonovitch was the first to propose fabrication of a 3D periodic structure that would enable manipulating the propagation of light due to its subwavelength structure [1]. When, four years later, the first artificial photonic crystal was produced by his group, this began a new direction in optics focused on designing and manufacturing of such objects. Currently, photonics is a rapidly developing field with diversified devices proposed that are capable of controlling different aspects of light propagation [2].

For manufacturing photonic structures a number of different techniques exist - e.g. oblique angle deposition [3], nanoimprint lithography [4], electron or focused ion beam lithography [5], and two-photon photolithography [6]. In particular, the last one, also known as Direct Laser Writing (DLW), is becoming very popular nowadays, being the fast-prototyping method for fabrication of micrometer-scale objects.

However, as far as DLW is concerned, the complexity of this technique makes its practical implementation difficult. On the contrary, it was shown that a range of microstructures can be fabricated by hot embossing [7], which provides a straight- 
forward way for commercial manufacturing. In the following, we present a simple fabrication technique for integration of almost arbitrarily shaped microstructures directly on the tip of an optical fibre.

This paper is a review of the research works on fabrication of optical microstructures by DLW that have been carried out at the Photonic Nanostructure Facility, University of Warsaw.

\section{DIRECT LASER WRITING: THEORY}

The idea behind most photolithographic techniques is to solidify a liquid (or dissolve a solid) substance, called resist, by initiating a definite set of chemical reactions with light. Typically, a resin might contain chemical compounds, known as photoinitiators, which can absorb light and, as a result, change their chemical properties. After that, a chain reaction begins, leading to the polymerization in the resin material. Its non-solidified portion can then be rinsed with a solvent, leaving the material only in the previously exposed regions. Such process is called negative photolithography, as opposed to the positive one, where the irradiated parts of a solid (or a gel-like) resin are finally dissolved. Using masks of arbitrary shape it is possible to create two-dimensional (plain) structures with the resolution of the same order as the wavelength of light. However, the fundamental problem arises with manufacturing 3D objects: since the resin absorbs in the whole volume illuminated by the light beam, it is impossible to solidify only one chosen plane in the beam propagation direction.

The DLW technique based on two-photon absorption (2PA) phenomena is devoid of this disadvantage. Since 2PA may occur only at high light intensities (such as those reached in a tightly focused laser beam) it is possible to achieve absorption only in a finite volume of the resin having the size of the beam focus. The resins must not absorb any light in a normal (linear) way at its wavelength, so that only two-photon phenomena can occur.

\section{DIRECT LASER WRITING: EXPERIMENTAL}

We used a commercially available setup (Photonic Professional, Nanoscribe $\mathrm{GmbH}$ ) [8]. The whole apparatus consists of near-infrared femtosecond Er-fibre frequency-doubled laser (central wavelength $780 \mathrm{~nm}, 150 \mathrm{fs}-$ long pulses at $100 \mathrm{MHz}$ repetition rate) and an inverted optical microscope (Zeiss, Axio Observer). Femtosecond laser pulses are used to increase the instantaneous light intensity even further, while the role of the microscope is to tightly focus the laser beam on (or slightly above) the surface of a glass plate placed over the objective (usually standard microscope slip glass) - the substrate for the microstructures (see Fig. 1). The cover-glass was placed on a piezo-translational XYZ stage, which allowed us to change the position of the focus with respect to the substrate and thus to solidify the structure in an arbitrarily chosen shape. To write the structures we used $100 \times \mathrm{NA}=1.4$ Zeiss Plan-Apochromat immersion-oil objective and commercially available IP-L negative photoresist. 
Among main factors defining the DWL setup resolution are: the translation stage accuracy, the size of the focus, and the properties of resin. With the built-in piezo- motors the positioning does not affect the resolution; the laser beam focus itself (called the voxel) is an ellipsoid with the diameter of $\sim 420 \mathrm{~nm}$ in the direction parallel to the glass surface and $\sim 1000 \mathrm{~nm}$ in the perpendicular one (see Fig. 1). Other properties of the photoresist, including bonding effect and surface roughness, are discussed in the following sections.

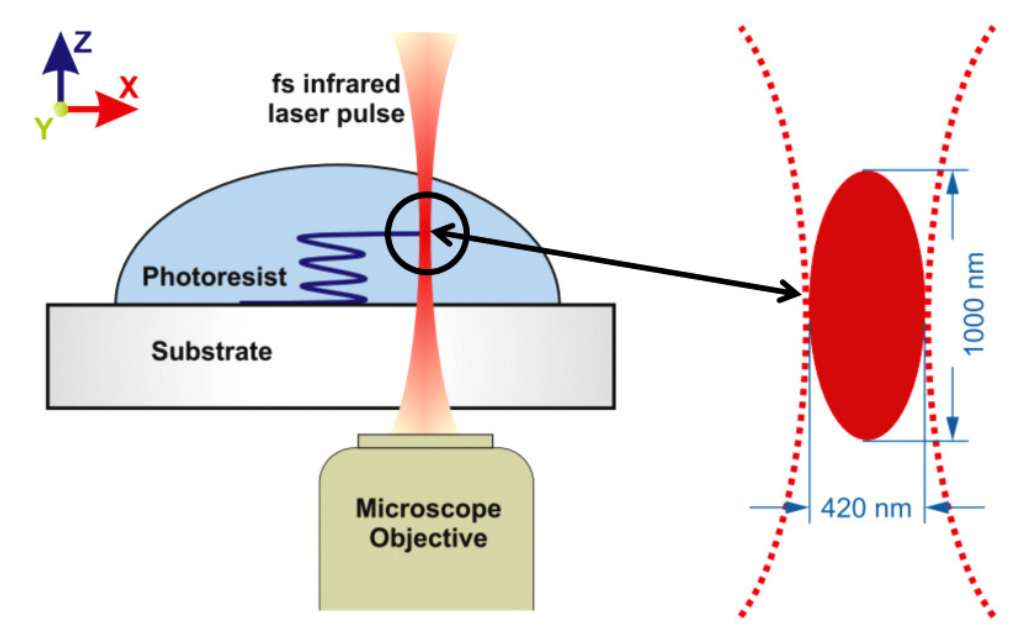

Fig. 1. Schematic of the DLW setup. Femtosecond pulses from a fibre laser reach the inverted microscope, where they are focused within the liquid photoresist placed on a $170 \mu \mathrm{m}$ thick microscope cover-glass substrate. The threshold energy for polymerization initiation is reached only in a small ellipsoid in the beam focus (the voxel).

The voxel size is changing with the light intensity, which can easily be seen on a series of parallel lines written with different laser powers [9]. Another technique to achieve variable line size is based on adjusting the relative depth of the structures with respect to the substrate (Fig. 2). The bonding effect - joining of two closely spaced lines - reduces the available printing resolution.
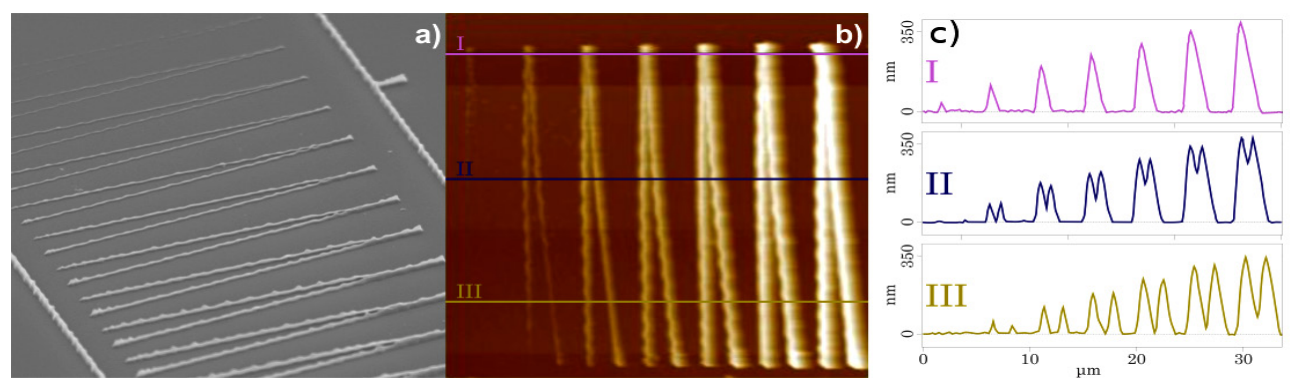

Fig. 2. SEM image of a series of V-shape structures fabricated in the IP-L liquid polymer photoresist (a). Corresponding AFM image (b) with three cross-section profiles (c). Depending on the absorbed laser power and the line depth relative to the substrate the line width varies. The measured height and lateral line width are in the ranges $30-370 \mathrm{~nm}$ and $200-480 \mathrm{~nm}$, respectively. 
Using the method and the setup described above, we had fabricated a matrix of diffractive gratings which act as colour filters (Fig. 3). Different grating constants shift the diffraction efficiency maximum to different wavelengths, thus creating a wide range of hues in the zeroth order transmission. The filters can be used e.g. on an optical chip, packed closely next to each other.

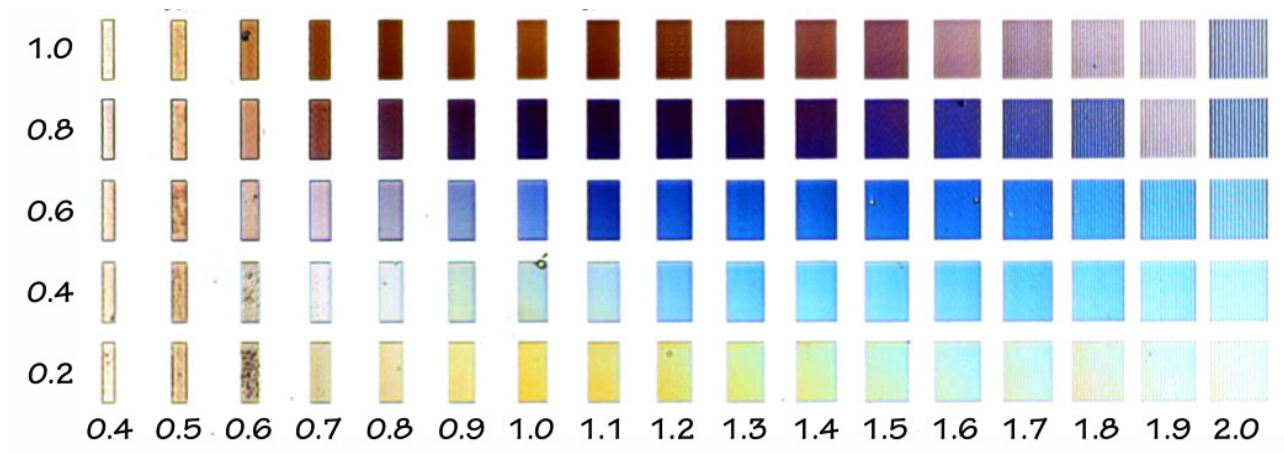

Fig. 3. White light transmission photography of phase gratings fabricated on a glass substrate. The single $30 \mu \mathrm{m}$ long and 0.2-1.0 $\mu \mathrm{m}$ high line and the grid spacing of 0.4-2.0 $\mu \mathrm{m}$ determine the transmission profiles in the zeroth diffraction order. The colour balance is adjusted to give the white background.

Among the greatest features of the two-photon 3D photolithography is its full free-form capability [6]. Using the workstation installed in the Photonic Nanostructure Facility $(\mathrm{PNaF})$, we were able to transform any bitmap, vector or CAD design directly into the polymer structure. In Fig. 4 it is shown that filling factor $z$ of the solidified photosensitive resin affects the quality of structures.

a)
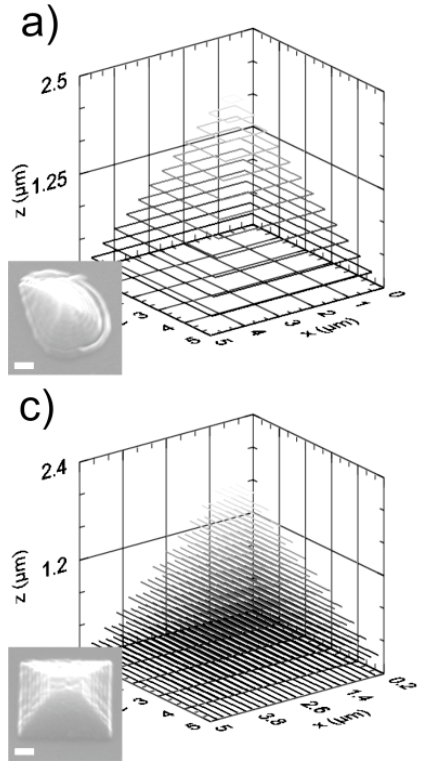

b)
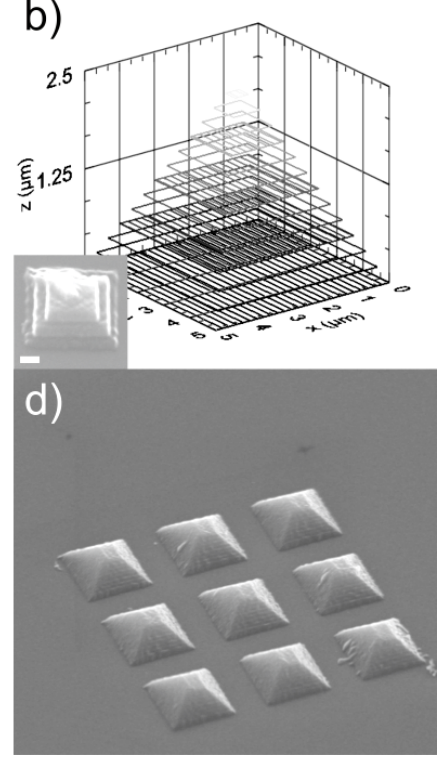

Fig. 4. Dependence of the structure quality on filling factor $z$ (a-c); SEM image of the matrix of 2.5 $\mu \mathrm{m}$ high pyramids, with potential application in microfluidic devices (d). Turbulence on such structures could improve mixing of liquid reagents. 


\section{DIRECT LASER WRITING ON A FIBRE TIP: EXPERIMENTAL}

The DWL setup was also used to fabricate optical microstructures directly on an optical fibre tip. Figure 5 shows the necessary modification of the setup.

In order to perform the DLW process on a fibre, its cleaved surface has to be used as a substrate. The fibre tip is inserted into a drop of photoresist with a translation stage, placed on the Nanoscribe workstation piezo-driven stage. Next, the fibre surface position must be identified. The XY position can be defined with the built-in CCD camera system - the light of a red LED (non-photopolymerizing) is coupled into the fibre, and its core can be found by scanning the sample. To enable visualization of the fibre tip surface, a second fibre is mounted on the translation stage. The light of another red LED is coupled into it and the fibre is placed higher and tilted with respect to the first one, to enable illumination of the whole sample (compare Fig. 5). The $\mathrm{Z}$ position is found with default Define Focus technique (Zeiss). However, in comparison to the regular DLW process, its precision is limited. Probably because of the small fibre surface size $(125 \mu \mathrm{m}$ in diameter for the SMF-28) the accuracy of technique is approximately $100 \mathrm{~nm}$. Finally, the DLW is performed downwards, starting from the fibre tip surface. After the writing process the photoresist is developed in 2-propanol to remove the unexposed part.

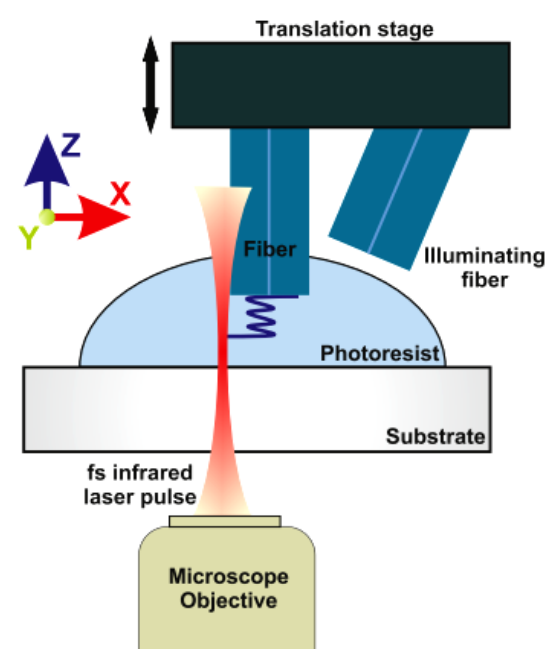

Fig. 5. Modification of the DLW setup for microfabrication on optical fibre tips (not to scale).

To enable the fabrication of high-quality structures the substrate fibre tilt and movement during the writing process have to be minimized. Unlike the authors of [10], we did not encounter problems with the fibre relative movement. However, the tilt introduced significant imperfections, which are especially important when the height of the structure is a critical parameter [11]. The fibre tilt can be introduced in different stages of the fabrication process: first of all, in the fibre cleaving the imperfections may arise. Usually, cleaving does not introduce the angle error higher than $0.5^{\circ}$, and the surface can be examined prior to the writing process. It is not the case for the tilt due to imperfections in mounting the fibre on the translation stage and the stage tilted with respect to the DWL setup platform. The total error usually varies in a range of $0.5-2^{\circ}$. 
To reduce the tilt, the following procedure was applied. First, the tilt of the fibre was measured by finding the position of the resin-fibre glass interface in different positions on the surface. Then, the measured tilt is taken into account by correcting the DLW script coordinates of the designed structure. Figure 6 shows a row of micropillars designed to have the same height fabricated with (b) and without (a) correcting the tilt. Without the correction the height of the pillars decreases from 1.5 $\mu \mathrm{m}$ to $750 \mathrm{~nm}$, over the distance of $32 \mu \mathrm{m}$, corresponding to the tilt of $1.34^{\circ}$. After the correction, the tilt was reduced to $0.07^{\circ}$. The residual tilt is caused by the inaccuracy of the Define Focus technique.

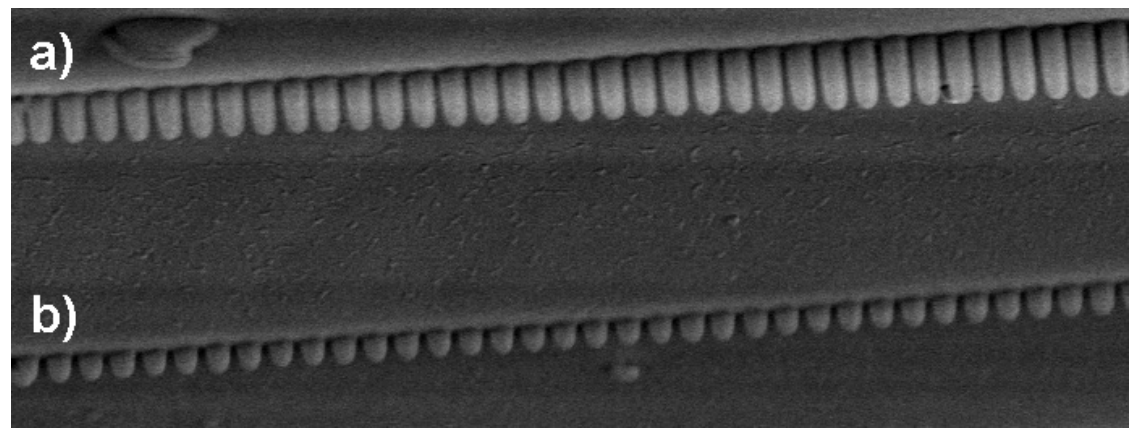

Fig. 6. Fibre tilt correction. The row of the micropillars fabricated without correcting the tilt (a). The row of micropillars (of a lower designed height) after successful application of the tilt correction procedure (b).

Two examples of microstructures fabricated on a fibre surface are shown in Fig. 7. While the 2D inscription shown in (a) does not represent significant value in terms of applications, it is clear that efficient fibre integration of microoptical devices, such as plano-convex microlens (b), can be useful for e.g. communication, fibre optics or optomechanics.

The idea of fibre-integrated microlenses dates back to 1970 s, when it was demonstrated that it can increase the efficiency of fibre coupling of the laser light [12, 13]. This was followed by theoretical description and concepts of new applications [14]. The lenses can be generated with a variety of microstructuring techniques - e.g. beam etching [15]. There has also been a significant effort invested in using DLW as the fabrication technique, which was shown to be advantageous due to its speed, full control over geometrical features of the structure, and high surface quality $[10,16,17]$.

One of the most important parameters of a microlens is the surface quality. In our work, to obtain the best possible surface, instead of the conventional parallel linear scanning mode, we employed the annular scanning mode technique with variable scanning intervals [16]. To optimize the fabrication process it is necessary to find the maximum distance between two consecutive concentric circles (annular steps). This was done by examining the surface of the samples with different annular steps using an atomic force microscope (AFM). The maximum step for which the surface was still continuous was found to be $150 \mathrm{~nm}$. The entire AFM profile of the sample's surface fabricated with this step is shown in Fig. 7 (c). Except for a few grains, the surface roughness remains in the range of 20-25 $\mathrm{nm}$. 

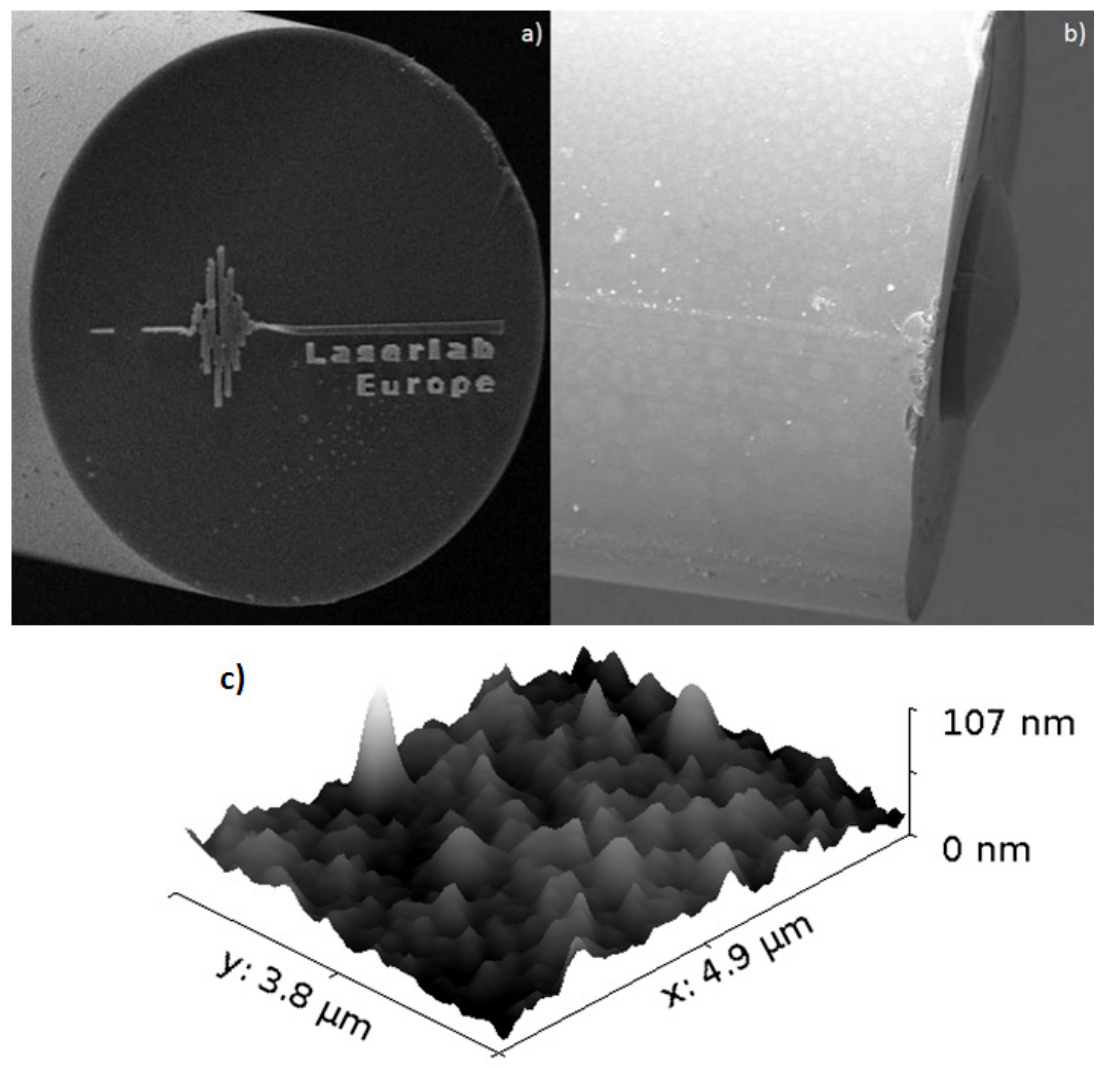

Fig. 7. Fibre-integrated microstructures: a) 2D Laserlab Europe logo fabricated on a SMF-28 fibre tip; b) plano-convex microlens centred on the HI-1060 fibre core;

c) AFM surface smoothness profile of the lens.

\section{DLW ON A FIBRE TIP: RESULTS}

Another example of a micro-optical structure fabricated on the fibre tip using the setup described previously is the gradient-index antireflective (AR) coating.

Ideally, one could expect a fibre to emit light with the same intensity as it was coupled in, when neglecting internal losses. However, fibre's transmittance is always lower, because some portion of light is lost due to the Fresnel back reflection. This process, originating from refractive index mismatch at the interface between fibre core and air, introduces optical loss, reduction of which is essential for many high-efficiency applications. Therefore, a variety of antireflection coatings are used to improve fibre decoupling efficiency, occupying an important place in the fibre laser technology and associated techniques. The Fresnel reflection can also be reduced using nanostructured gradient-index AR coatings [18, 19]. If such a coating is fabricated directly on the fibre tip and has the refractive index gradually changing along the longitudinal axis $(Z)$ from the refractive index of the core to that of ambient medium (typically air), it can significantly reduce the reflectivity over a very broad spectral range. 


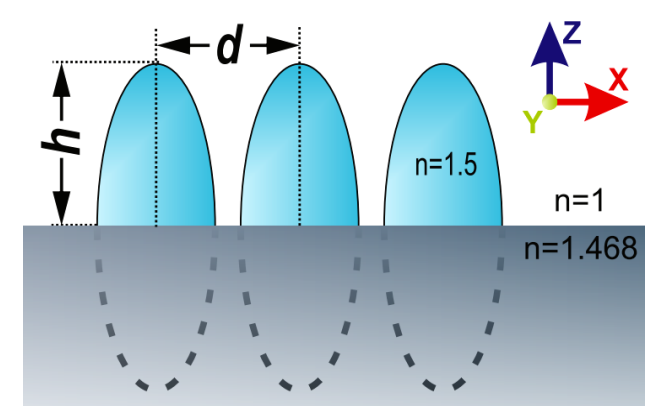

Fig. 8. Fibre-integrated gradient-index antireflective coating. The hemi-ellipsoids $(\mathrm{n}=1.52)$ with a given height $h$ and spacing $d$ are fabricated at the interface between the fibre core $(\mathrm{n}=1.468)$ and air $(\mathrm{n}=1)$. Dashed line shows a half of the voxel exposed inside the fibre thus not causing photopoly-merization.

Figure 8 shows an array of sub-micrometric hemi-ellipsoids which can act as a very efficient gradient AR coating. Such an array can be fabricated by exposing the single writing points (voxels) directly at the interface between the resist and the fibre. Since one half of the voxel will be exposed inside the glass, only the second half will cause solidification of the resist. As the shape of the voxel is ellipsoidal (compare Figs. 1 and 8), the refractive index of the structure will smoothly change along the Z-axis. The effective refractive index of the structure can be modified by changing the free parameters: height $h$ and spacing $d$. In our work, the geometry of the structure was optimized by finding the minimum of the back-reflectivity for the single mode SMF-28 fibre at $1550 \mathrm{~nm}$. Details of the design procedure, fabrication and measurements can be found in [11].

Because of the shape and size of the structure, it is crucial to precisely find the substrate interface position. Previously mentioned inaccuracy of the Define Focus technique caused several problems in fabrication process and required several repetitions until the desired parameters were obtained. Moreover, the uncompensated fibre tilt can affect the quality of the structure, as the height of the single hemiellipsoids will not be constant. Nevertheless, it was shown that the height of the structure is not a critical parameter, so this can act as efficient AR coating even when there are significant discrepancies from the designed geometry [11].

Figure 9 shows an example of the fibre-integrated AR coating. Although due to the experimental imperfections it was not possible to fabricate the structure with a constant optimal height, the Fresnel reflection was still decreased by a factor of 30 at $1550 \mathrm{~nm}$. If correctly fabricated, the structure does not introduce any scattering and the beam shape is not distorted [11].

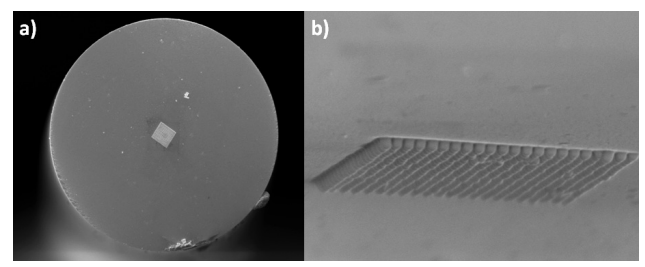

Fig. 9. SEM picture of the gradient-index antireflective coating centred on the core of the SMF-28 fibre $125 \mu \mathrm{m}$ in diameter (a). Oblique view of the array of hemi-ellipsoids - the single row is approx. $10 \mu \mathrm{m}$ long (b). 


\section{CONCLUSIONS}

We have demonstrated a way of harnessing the two-photon absorption in order to make micro-optical components. Besides showing simple diffraction gratings acting as colour filters in the visible range, we successfully tested the proposed technique of writing microstructures directly on the optical fibre tip.

The increasing availability of the 3D printing technique would widen the scope of its possible applications in the near future.

\section{ACKNOWLEDGEMENTS}

This work has been generously supported by the National Science Center (Poland) within the DEC-2012/05/E/ST3/03281 grant funds. Partial support by ERDF within the POIG.02.01.00-14-122/09-00 is also acknowledged.

\section{REFERENCES}

1. Yablonovitch, E. (1987). Inhibited spontaneous emission in solid-state physics and electronics, Phys. Rev. Lett., 58, 2059-2062. DOI: 10.1103/PhysRevLett.58.2059.

2. Joannopoulos, J.D. (2011). Photonic Crystals: Molding the Fow of Light. Princeton University Press.

3. Hadobas, K., Kirsch, S., Carl, A., Acet, M., \& Wassermann, E.F. (2000). Reflection properties of nanostructure-arrayed silicon surfaces. Nanotechnology, 11, 161-164. DOI: 10.1088/0957-4484/11/3/304.

4. Reboud, V., Kehoe, T., Vivas, J.R., Kehagias, N., Zelsmann, M., Alsina, F., \& Sotomayor Torres, C.M. (2012). Polymer photonic band-gaps fabricated by nanoimprint lithography. Phot. Nano. Fund. Appl., 10, 632-635. DOI: 10.1016/j.photonics.2012.06.001.

5. Rosolen, G. \& Cola, A. (6-8 Dec., 2006). Fabrication of Photonic Crystal Structures by Electron Beam Lithography. Conf. on Optoelectronic and Microelectronic Materials and Devices, 66-69. DOI: 10.1109/COMMAD.2006.4429881

6. Maruo, S., Nakamura, O., \& Kawata, S. (1997). Three-dimensional microfabrication with two-photon-absorbed photopolymerization. Opt. Lett., 22, 132-134. DOI: 10.1364/ OL.22.000132

7. Kim, K., Park, S., Lee, J., Manohara, H., Desta, Y., Murphy, M., \& Ahn, C. H., (2002). Rapid replication of polymeric and metallic high aspect ratio microstructures using PDMS and LIGA technology. Microsyst. Technol., 9 (1-2), 5-10 (2002).

8. Rill, M. S. (2010). Three-Dimensional Photonic Metamaterials by Direct Laser Writing and Advanced Metallization Techniques. PhD dissertation, Chap. 3, http://digbib.ubka. uni-karlsruhe.de/volltexte/1000018614

9. Zeng, H., Martella, D., Wasylczyk, P., Cerretti, G., Lavocat, J-C.G., Ho C-H, Parmeggiani, C., \& Wiersma, D. (2014). High-Resolution 3D Direct Laser Writing for LiquidCrystalline Elastomer Microstructures. Advanced materials, 26, 2319-22.

10. Williams, H.E., Freppon, D.J., Kuebler, S.M., Rumpf, R.C., \& Melino, M.A. (2011). Fabrication of three-dimensional micro-photonic structures on the tip of optical fibers using SU-8. Opt. Express, 19, 22910-22922. DOI: 10.1364/OE.19.022910. 
11. Kowalczyk, M., Haberko, J., \& Wasylczyk, P. (2014). Microstructured gradient-index antireflective coating fabricated on a fiber tip with direct laser writing. Opt. Express, 22, 12545-12550. DOI: 10.1364/OE.22.012545.

12. Cohen, L.G., \& Schneider, L.V. (1974). Microlenses for coupling junction lasers to optical fibers. Appl. Opt., 13(1), 89-94. DOI: 10.1364/AO.13.000089.

13. Bear, P.D. (1981) Microlenses for coupling single-mode fibers to single-mode thin-film waveguides. Proc. SPIE, 0239. DOI: 10.1117/12.959193.

14. Lee, K.S., \& Barnes, F.S. (1985). Microlenses on the end of single-mode optical fibers for laser applications. Appl. Opt., 24, 3134-3139. DOI: 10.1364/AO.24.003134.

15. Hadobas, K., Kirsch, S., Carl, A., Acet, M., \& Wassermann, E.F. (2000) Reflection properties of nanostructure-arrayed silicon surfaces. Nanotechnology, 11, 161-164. DOI: $10.1088 / 0957-4484 / 11 / 3 / 304$

16. Guo, R., Xiao, S., Zhai, X., Li, J., Xia, A., \& Huang, W. (2006). Microlens fabrication by means of femtosecond two photon photopolymerization. Opt. Express, 14, 810-816. DOI: 10.1364/OPEX.14.000810 (metoda rysowania)

17. Žukauskas, A., Malinauskas, M., Reinhardt, C., Chichkov, B.N., \& Gadonas, R. (2012). Closely packed hexagonal conical microlens array fabricated by direct laser photopolymerization. Appl. Opt., 51, 4995-5003. DOI: 10.1364/AO.51.004995.

18. Schallenberg, U.B. (2011). Nanostructures versus thin films in the design of antireflection coatings. Proc. SPIE, 8168-59. DOI:10.1117/12.896841.

19. Schulz, U. (2006). Review of modern techniques to generate antireflective properties on thermoplastic polymers. Appl. Opt., 45, 1608-1618. DOI: 10.1364/AO.45.001608.

\title{
OPTISKU MIKROSTRUKTŪRU IZVEIDE, IZMANTOJOT TIEŠO LĀZERA LITOGRĀFIJU
}

\author{
M. Kowalczyk, M. Nawrot, and L. Zinkiewicz
}

K o p s a vi $1 \mathrm{ku} \mathrm{m} \mathrm{s}$

Trīsdimensiju fotolitogrāfija, pazīstama arī kā tiešā lāzera litogrāfija, ir metode, ar kuras palīdzību ir iespējams ražot fotoniskas mikrostruktūras. Šajā rakstā aplūkoti tiešās lāzera litogrāfijas tehnoloǵijas pamati, kā arī nozīmīgākie jautājumi, kas saistīti ar ražošanas procesu. Uzrādīti vairāku optisku mikroierīču dizaina un ražošanas procesa eksperimentālie rezultāti. Nozīmīgākie piemēri ir uz difrakcijas režǵiem bāzēti krāsu filtri, optiskās šķiedras galā integrētas lēcas vai pretatstarošanās pārklājumi telekomunikācijās izmantotajam viļņa garumam $(1550 \mathrm{~nm})$. Pêtījuma rezultāti parāda, ka tiešā lāzera litogrāfija ir perspektīva ātrās prototipu radīšanas metode, kas var nodrošināt vieglu pieejamību optisko materiālu fotoniskajām īpašībām. 